\title{
OPEN Yolk-shell structured magnetic mesoporous silica: a novel and highly efficient adsorbent for removal of methylene blue
}

\author{
Reza Mirbagheri, Dawood Elhamifar ${ }^{\bowtie}$ Masoumeh Shaker \\ In this study, a novel magnetic mesoporous silica with yolk-shell structure $\left(\mathrm{Fe}_{3} \mathrm{O}_{4} @\right.$ Void@m.SiO $\left.{ }_{2}\right)$ \\ was successfully synthesized via a polymer-template assisted method. The $\mathrm{Fe}_{3} \mathrm{O}_{4}$ @Void@m.SiO \\ was characterized by using FT-IR, EDS, SEM, TEM, VSM, PXRD and nitrogen adsorption-desorption \\ analyses.The $\mathrm{Fe}_{3} \mathrm{O}_{4} @$ QVoid@m. $\mathrm{SiO}_{2}$ nanocomposite showed high efficiency in adsorption of an organic \\ dye and water pollutant called methylene blue (MB) with $98.2 \%$ removal capability. Furthermore, the \\ effect of different parameters in the adsorption of MB was investigated. Different models of kinetic \\ were examined and compared with each other. The recoverability and reusability of designed $\mathrm{Fe}_{3} \mathrm{O}_{4} @$ \\ Void@m.SiO 2 material were also studied under applied conditions.
}

After the first report about interesting materials with yolk-shell (YS) structure ${ }^{1}$, many researches have developed the synthesis methods and properties of these materials with different names such as nanorattle ${ }^{2}$, movable core/ shell ${ }^{1}$, core/shell with hollow interiors ${ }^{3}$ and yolk $/$ shell $^{4}$. These nanomaterials are in the center of attention due to interesting properties such as high surface area, interstitial hollow space and low density ${ }^{5,6}$. These special properties make yolk-shell nanocomposites suitable to use in the fields of biomedical ${ }^{7}$, lithium batteries ${ }^{8,9}$, sensors ${ }^{10,11}$, catalysis ${ }^{12-16}$ and adsorption ${ }^{17,18}$. Some of recently reported yolk-shell structured materials are $\mathrm{Sn}_{4} \mathrm{P}_{3} @ \mathrm{C}^{19}, \mathrm{Sn} @$ $\mathrm{SnO} / \mathrm{SnO}_{2}{ }^{20}, \mathrm{Al} @ \mathrm{TiO}_{2} \mathrm{NPs}^{21}$ and $\mathrm{Au}-\mathrm{CeO}_{2} @ \mathrm{ZrO}_{2}{ }^{22}$. Among different shells, silica-based ones is more important in catalysis and adsorption processes owing to its high loading capacity compared to other shells $\mathrm{s}^{23,24}$. The preparation methods effect on features of the yolk, space, thickness, porosity and shape of YS materials. The more common methods used for the preparation of YSs are hard temple-assisted, soft template-assisted and templatefree $^{25}$. Among these, the soft template method has attracted more attention due to easy removal of template and also economically friendly ${ }^{26,27}$.

Moreover, owing to superparamagnetic properties, easy separation and low toxicity, magnetic nanoparticles (MNPs) have been so interested in different fields such as biomedical ${ }^{28,29}$, magnetic resonance imaging ${ }^{30}$, drug delivery $^{31}$ and separation ${ }^{32}$. However, the most of MNPs suffer from disadvantages of aggregation, biodegradation and low capacity. In order to increase the stability and capacity, these NPs are composited with different species. Among different species, mesoporous silica is more attracted because of its high surface area, high pore volume and high capacity ${ }^{33-35}$.

As regards to water purification importance and lots of different pollutants that made by pharmaceutical, paper making, textile, leather, etc., different methods such as photocatalytic degradation, adsorption and oxidation have been used to eliminate water pollutant $s^{36,37}$. To date many adsorbents have been applied for the elimination of organic and inorganic pollutants from water. Among these, magnetic NPs have attracted more attention due to the advantages of easy magnetically separation, economically friendly and high efficiency. Some of recently developed systems are magnetic zeolites ${ }^{38}$, magnetic carbon nanotubes composites ${ }^{39}, \mathrm{Zn} /$ ferrite/ graphene oxide ${ }^{40}$ and activated carbon/ $\mathrm{NiFe}_{2} \mathrm{O}_{4}{ }^{41}$. Although these adsorbents gave good to high efficiency in the removal of water pollutants, however, in spite of high adsorption capacity of the yolk-shell based magnetic nanocomposites, according to our knowledge, there is no report in the study of efficiency of these type nanomaterials in the removal of water pollutants. In view of the above, herein, a novel magnetic $\mathrm{Fe}_{3} \mathrm{O}_{4} @$ mesoporous silica nanocomposite $\left(\mathrm{Fe}_{3} \mathrm{O}_{4} @\right.$ Void@m. $\left.\mathrm{SiO}_{2}\right)$ with yolk-shell structure and high magnetic properties is prepared for adsorption of methylene blue (MB) from water. The kinetics, isotherm and equilibrium data for adsorption of MB have been analyzed and different models have been employed to understand the mechanism. 


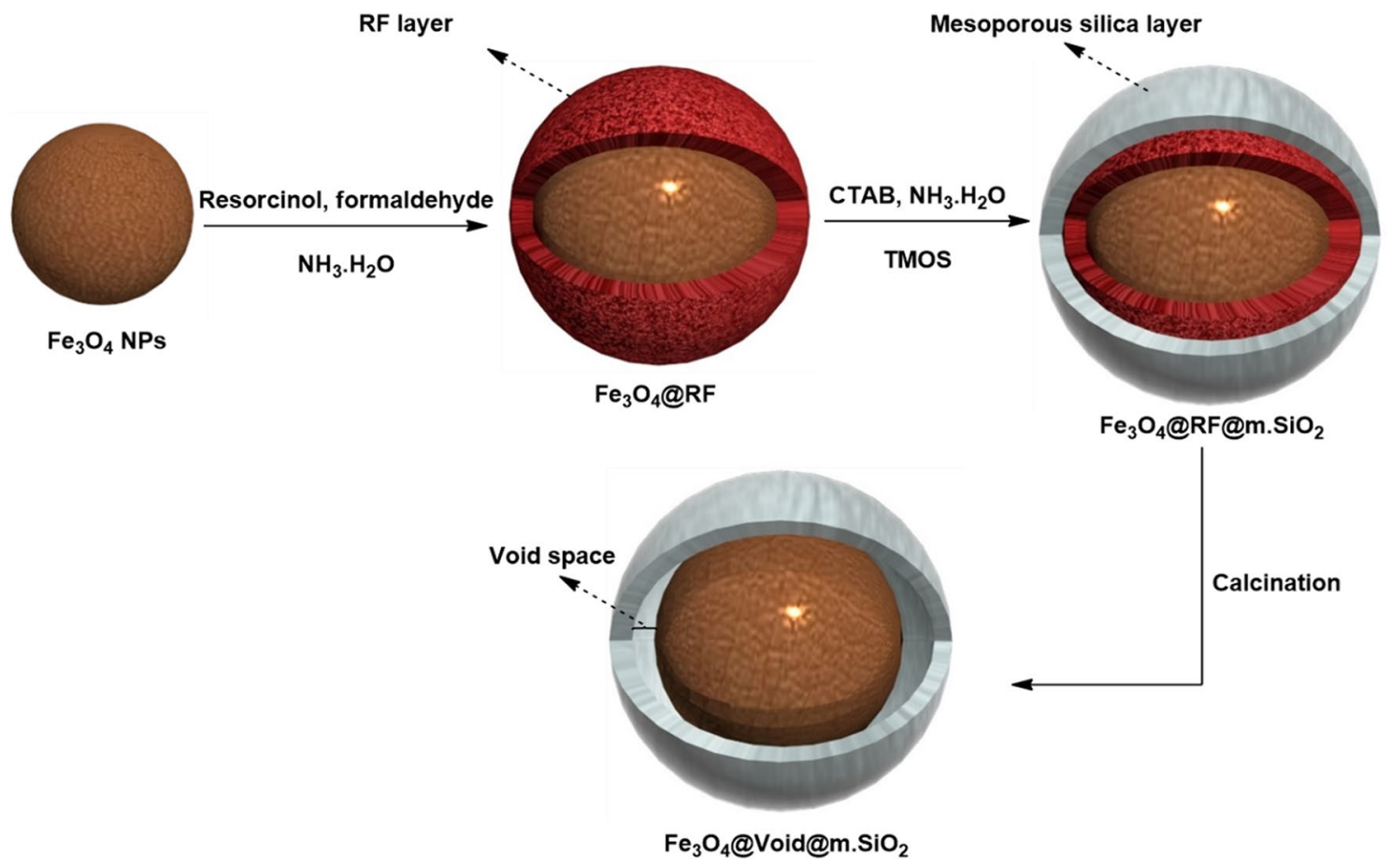

Figure 1. Preparation of $\mathrm{Fe}_{3} \mathrm{O}_{4} @ V$ Void@m.SiO ${ }_{2}$.

\section{Experimental section}

Preparation of $\mathrm{Fe}_{3} \mathrm{O}_{4}$ @Void@m.SiO $\mathrm{Si}_{2}$ nanomaterial. To do this, firstly magnetic $\mathrm{Fe}_{3} \mathrm{O}_{4} \mathrm{NPs}_{\text {s }}$ were prepared ${ }^{42}$. In the second step, the $\mathrm{Fe}_{3} \mathrm{O}_{4} \mathrm{NPs}$ were modified with resorcinol-formaldehyde polymer to form $\mathrm{Fe}_{3} \mathrm{O}_{4} @ \mathrm{RF}$ material. In order to prepare $\mathrm{Fe}_{3} \mathrm{O}_{4} @ \mathrm{RF}$, the $\mathrm{Fe}_{3} \mathrm{O}_{4} \mathrm{NPs}(100 \mathrm{mg}$ ) were added to a mixture of EtOH $(20 \mathrm{~mL})$ and $\mathrm{H}_{2} \mathrm{O}(10 \mathrm{~mL})$ in an ultrasonic bath. Then, ammonium hydroxide $(0.5 \mathrm{~g}$, aqueous solution, $28 \mathrm{wt} \%)$, $\mathrm{HCHO}(0.1 \mathrm{~g}, 37 \mathrm{wt} \%)$ and resorcinol $(0.1 \mathrm{~g}, 0.09 \mathrm{mM})$ were added while stirring for $2 \mathrm{~h}$. After polymerization, the resulted $\mathrm{Fe}_{3} \mathrm{O}_{4} @ \mathrm{RF}$ was collected and washed completely with $\mathrm{H}_{2} \mathrm{O}$ and EtOH. Next, the as-made $\mathrm{Fe}_{3} \mathrm{O}_{4} @$ $\mathrm{RF}(0.12 \mathrm{mg})$ was dispersed in a mixture of CTAB $(0.45 \mathrm{~g})$, ammonia $(2 \mathrm{~mL}, 28 \mathrm{wt} \%), \mathrm{H}_{2} \mathrm{O}(100 \mathrm{~mL})$ and EtOH $(150 \mathrm{~mL})$. The resulted combination was stirred to form a homogeneous mixture. After adding of TMOS $(1.5 \mathrm{~mL})$, stirring was continued for $6 \mathrm{~h}$. The resulted $\mathrm{Fe}_{3} \mathrm{O}_{4} @ \mathrm{RF} @ \mathrm{~m} . \mathrm{SiO}_{2}$ material was washed completely with EtOH and $\mathrm{H}_{2} \mathrm{O}$. Finally, the RF layer and CTAB surfactant were removed after heating of the $\mathrm{Fe}_{3} \mathrm{O}_{4} @ \mathrm{RF} @ \mathrm{~m}$. $\mathrm{SiO}_{2}$ material at $550{ }^{\circ} \mathrm{C}$ for $6 \mathrm{~h}$ (Fig. 1). The final magnetic nanomaterial with yolk-shell structure was denoted as $\mathrm{Fe}_{3} \mathrm{O}_{4} @$ Void@m.SiO . $_{2}$

Adsorption process. For this, $5 \mathrm{mg}$ of the $\mathrm{Fe}_{3} \mathrm{O}_{4} @$ Void@m. $\mathrm{SiO}_{2}$ was added in $15 \mathrm{~mL}$ of an aqueous solution of $\mathrm{MB}$. This mixture was shaken continuously and the $\mathrm{Fe}_{3} \mathrm{O}_{4} @$ Void@m.SiO $\mathrm{S}_{2}$ was magnetically separated immediately. The MB concentration was measured by UV-vis at $665 \mathrm{~nm}$. The adsorption efficiency for $\mathrm{MB}$ in water solution was calculated by using Eq. (1).

$$
\text { adsorption efficiency }(\%)=\frac{C_{0}-C_{e}}{C_{0}} \times 100
$$

On the other hand, the amount of adsorbed MB on the adsorbent $\left(\mathrm{q}_{\mathrm{e}}\right)$ was calculated by using Eq. (2).

$$
\mathrm{q}_{e}=\frac{\left(C_{0}-C_{e}\right) \times V}{m}
$$

Herein, $\mathrm{C}_{0}$ and $\mathrm{C}_{\mathrm{e}}$ are, respectively, the concentration of the initial dye solution and the residual dye solution that quantitatively estimated by linear regression equations resulted at different dye concentrations, $\mathrm{V}$ is solution volume in liters and $\mathrm{m}$ is adsorbent amount $(\mathrm{mg})$.

\section{Results and discussion}

The magnetic mesoporous silica material $\left(\mathrm{Fe}_{3} \mathrm{O}_{4} @\right.$ Void@m.SiO $\left.{ }_{2}\right)$ with yolk-shell structure was prepared from an intermediate structure $\left(\mathrm{Fe}_{3} \mathrm{O}_{4} @ \mathrm{RF}\right)$ which was made by polymerization of $\mathrm{HCHO}$ and resorcinol (Fig. 2) on the $\mathrm{Fe}_{3} \mathrm{O}_{4} \mathrm{NPs}$ surface. The mesoporous silica shell was coated on the $\mathrm{Fe}_{3} \mathrm{O}_{4} @ \mathrm{RF}$ by using CTAB and TMOS via a sol-gel approach. Finally, RF and CTAB were eliminated to deliver $\mathrm{Fe}_{3} \mathrm{O}_{4} @$ Void@m.SiO $\mathrm{S}_{2}$ (Fig. 1). 
<smiles>[R]c1cccc(O)c1</smiles>

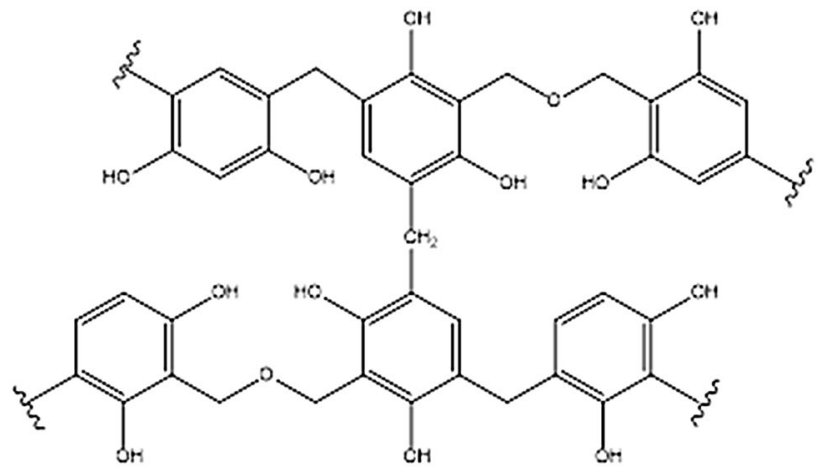

Figure 2. A suitable pathway for polymerization of formaldehyde and resorcinol.

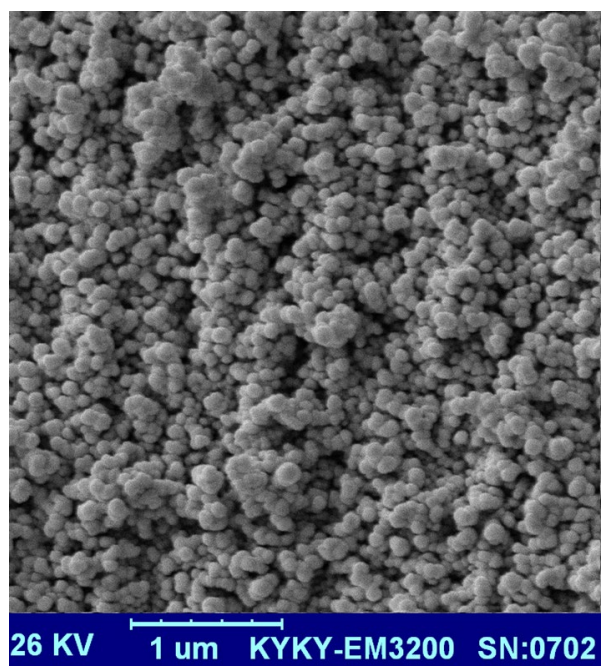

Figure 3. SEM image of the $\mathrm{Fe}_{3} \mathrm{O}_{4} @$ Void@m.SiO ${ }_{2}$ nanomaterial.

Characterization. The SEM image of $\mathrm{Fe}_{3} \mathrm{O}_{4} @ V$ Void@m. $\mathrm{SiO}_{2}$ yolk shell nanomaterial is illustrated in Fig. 3. As shown, the designed material has particles with spherical morphology and average size of $84 \mathrm{~nm}$. These types of NPs are excellent candidates for adsorption processes.

The TEM image of the $\mathrm{Fe}_{3} \mathrm{O}_{4} @$ Void@m. $\mathrm{SiO}_{2}$ nanomaterial also showed a yolk-shell structure with black cores $\left(\mathrm{Fe}_{3} \mathrm{O}_{4} \mathrm{NPs}\right)$ and mesoporous silica shell (Fig. 4).

The low-angle PXRD (LA-PXRD) pattern of $\mathrm{Fe}_{3} \mathrm{O}_{4} @$ Void@m. $\mathrm{SiO}_{2}$ showed an intense peak centered at 2 theta of 1 degree that is characteristic of nanomaterials with an ordered 2D hexagonal mesostructure (Fig. 5). These types of materials have high surface area and are very effective in the adsorption processes.

The wide-angle PXRD of $\mathrm{Fe}_{3} \mathrm{O}_{4} @ V$ Void@m.SiO $\mathrm{S}_{2}$ showed six reflection peaks at $2 \theta$ of $63^{\circ}, 57^{\circ}, 54^{\circ}, 43^{\circ}, 35^{\circ}$ and $30^{\circ}$ (Fig. 6). This pattern is in good agreement with the PXRD pattern of $\mathrm{Fe}_{3} \mathrm{O}_{4}$ NPs confirming high stability of the magnetite cores during material preparation. This analysis also showed a broad peak at 2 theta about 20 degree that is attributed to mesoporous silica shell ${ }^{42}$.

Figure 7 shows the vibrating sample magnetometer (VSM) analysis of the designed nanomaterial. As shown, this material has good magnetic property. As expected, due to the nonmagnetic mesoporous silica shell and the large void space, the magnetization is reduced from 60 for $\mathrm{Fe}_{3} \mathrm{O}_{4}$ to $15 \mathrm{emu} / \mathrm{g}$ for $\mathrm{Fe}_{3} \mathrm{O}_{4} @ \mathrm{Void} @ \mathrm{~m} \mathrm{SiO}_{2}{ }^{14}$.

The FT-IR spectra of $\mathrm{Fe}_{3} \mathrm{O}_{4}$ and $\mathrm{Fe}_{3} \mathrm{O}_{4} @$ Void@m.SiO $\mathrm{S}_{2}$ before and after calcination, are shown in Fig. 8. For all materials, the absorption peaks of Fe-O bonds are observed about $580 \mathrm{~cm}^{-1}$. The bands at $710-810 \mathrm{~cm}^{-1}$ are 


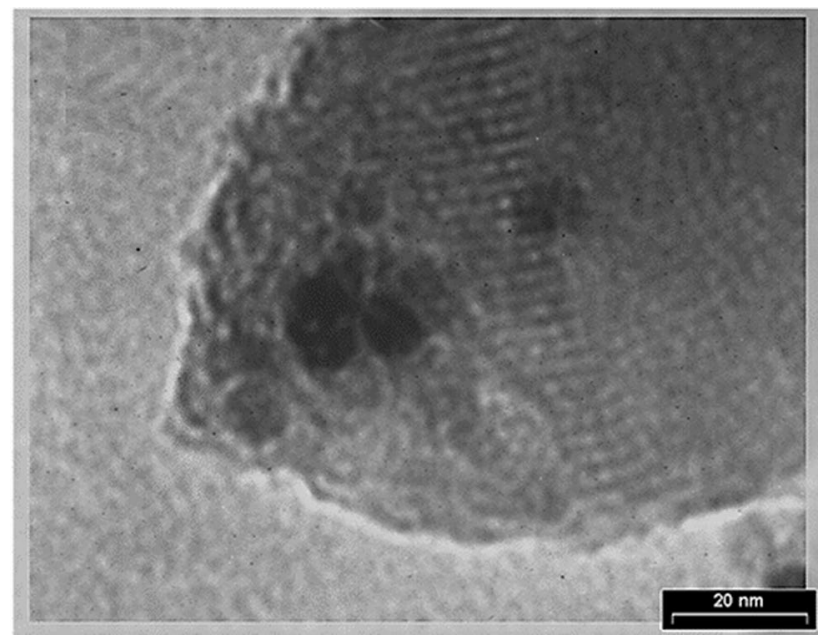

Figure 4. TEM image of $\mathrm{Fe}_{3} \mathrm{O}_{4} @ V$ Void@m.SiO ${ }_{2}$.

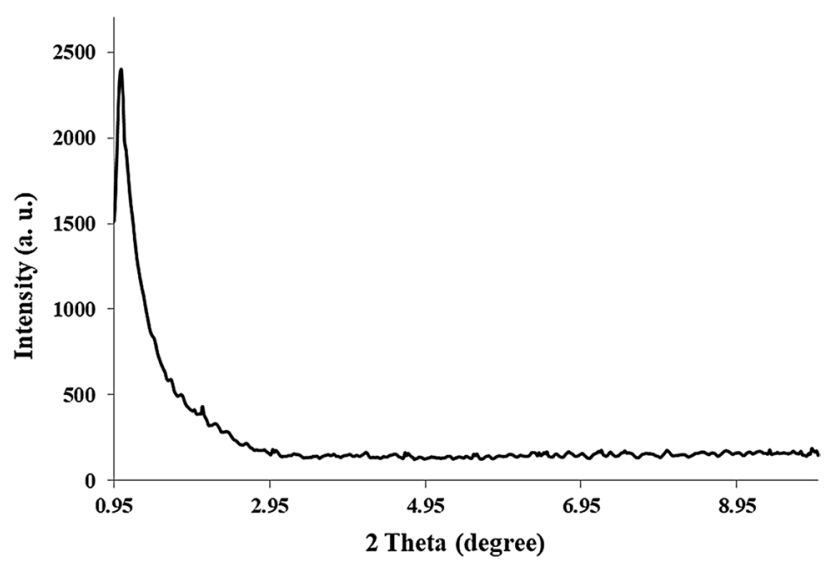

Figure 5. The low angle PXRD pattern of $\mathrm{Fe}_{3} \mathrm{O}_{4} @ \mathrm{Void} @ \mathrm{~m} \cdot \mathrm{SiO}_{2}$.

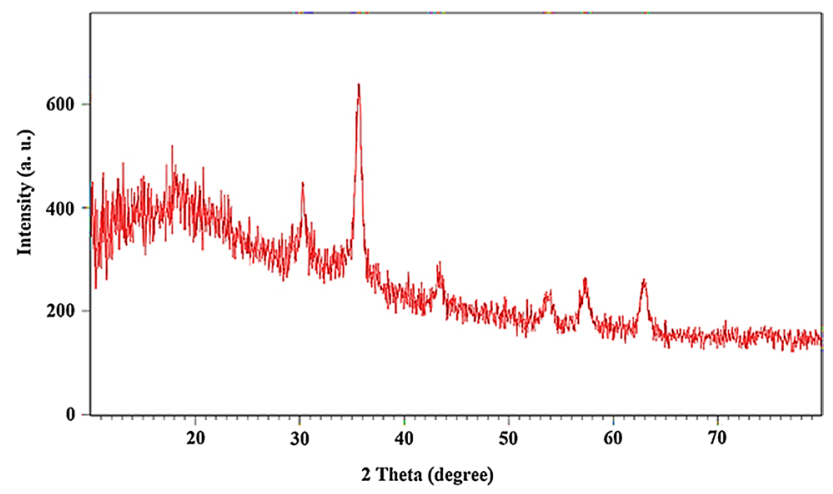

Figure 6. The wide-angle PXRD pattern of $\mathrm{Fe}_{3} \mathrm{O}_{4} @$ Void@m. $\mathrm{SiO}_{2}$.

due to $\mathrm{C}-\mathrm{Si}$. The peaks cleared at 1100 and $935 \mathrm{~cm}^{-1}$ are due to $\mathrm{Si}-\mathrm{O}-\mathrm{Si}$ bonds. The peak at $3500 \mathrm{~cm}^{-1}$ is owing to $\mathrm{O}-\mathrm{H}$ bonds of material surface. Before surfactant and $\mathrm{RF}$ removal, the peaks at 2850 and $2920 \mathrm{~cm}^{-1}$ are corresponded to aliphatic $\mathrm{C}-\mathrm{H}$ bonds of $\mathrm{CTAB}$ and peaks about $3020 \mathrm{~cm}^{-1}$ are related to aromatic $\mathrm{C}-\mathrm{Hs}$ of $\mathrm{RF}$ (Fig. 8B). Interestingly, the latter peaks are disappeared in Fig. 8C confirming successful removal of CTAB and RF during calcination. It is important to note that, to prepare a material with mesoporous yolk-shell structure, both CTAB (containing aliphatic $\mathrm{C}-\mathrm{H}$ ) and $\mathrm{RF}$ (containing aromatic $\mathrm{C}-\mathrm{H}$ ) should be romed. After removal of CTAB a mesoporous silica shell is resulted, while after removal of RF the void space between shell and core is resulted. 


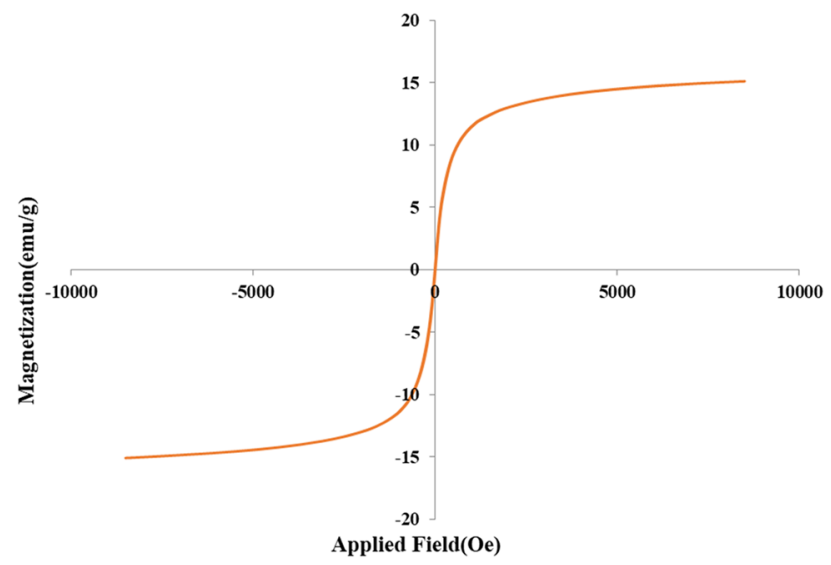

Figure 7. The VSM analysis of $\mathrm{Fe}_{3} \mathrm{O}_{4} @ V$ Void@m.SiO ${ }_{2}$.

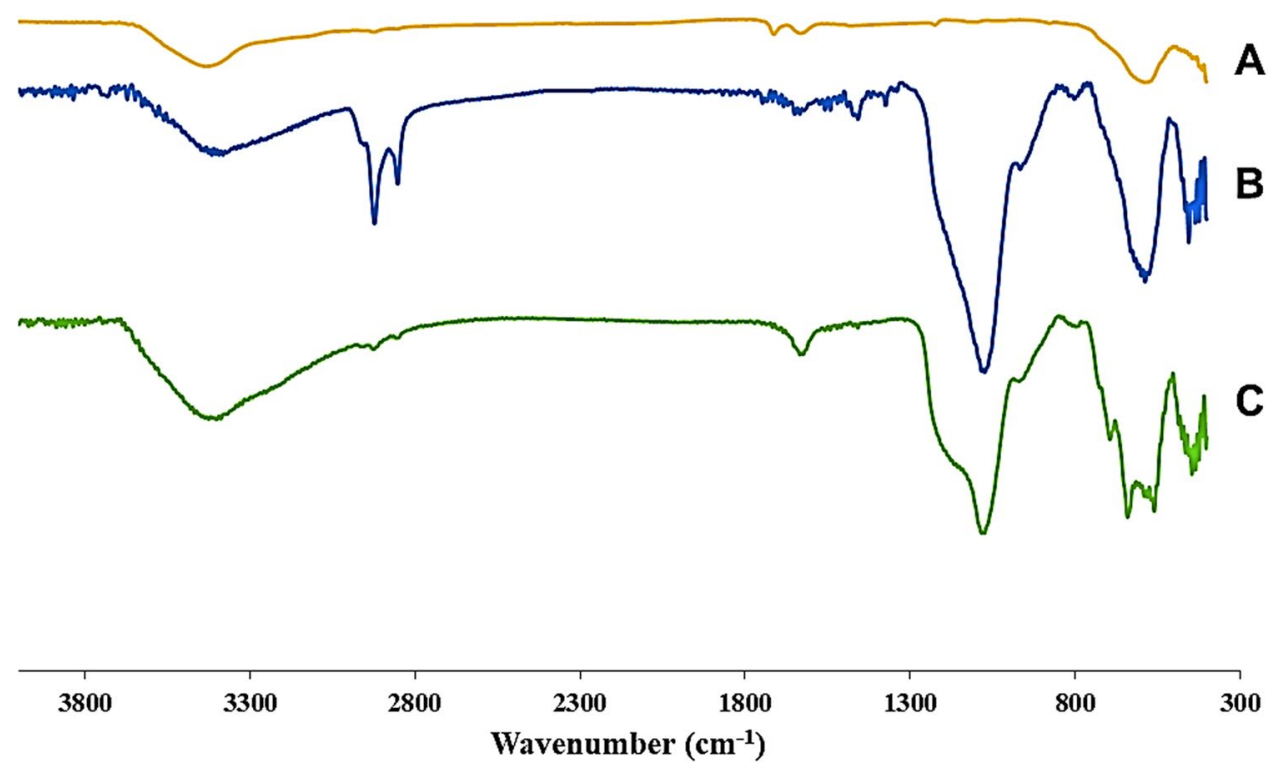

Figure 8. FT- $\mathrm{IR}$ results of $\mathrm{Fe}_{3} \mathrm{O}_{4}(\mathbf{A}), \mathrm{Fe}_{3} \mathrm{O}_{4} @$ Void@m. $\mathrm{SiO}_{2}$ nanomaterial before (B) and after $(\mathbf{C})$ calcination.

The EDS was performed for elemental analysis of the material before adsorption process (Fig. 9). This analysis clearly showed the existence of oxygen, iron and silicon confirming high stability and well incorporation of expected magnetite cores and silica shells in the material network.

The nitrogen adsorption-desorption isotherm of the $\mathrm{Fe}_{3} \mathrm{O}_{4} @$ Void@m.SiO $\mathrm{S}_{2}$ nanomaterial before adsorption process shows a type IV isotherm with an $\mathrm{H} 2$ hysteresis loop, which is characteristic of ordered mesostructures with high regularity (Fig. 10). The sharp capillary condensation steps occurred at a relative pressure of $0.45-0.97$, indicate the large void space of $\mathrm{Fe}_{3} \mathrm{O}_{4} @$ Void@m.SiO ${ }_{2}$ and the porous silica shell ${ }^{43}$. The Brunauer-Emmett-Teller (BET) surface area and total pore volume of the material were also found to be $666.16 \mathrm{~m}^{2} / \mathrm{g}$ and $1.28 \mathrm{~cm}^{3} / \mathrm{g}$, respectively. The Barrett-Joyner-Halenda $(\mathrm{BJH})$ pore size distribution isotherm showed a bimodal size distribution at 7.1 and $12.2 \mathrm{~nm}$ related to the mesoporous shell and void space between yolk and shell, respectively (Fig. 11). These data are in good agreement with LA-PXRD and TEM results confirming the presence of a mesoporous shell and yolk-shell structure for the designed nanomaterial.

Adsorption Studies. The elimination of MB, as organic dye, was examined as a model to study adsorption ability of synthesized $\mathrm{Fe}_{3} \mathrm{O}_{4} @$ Void@m.SiO $\mathrm{S}_{2}$ material. The time, dye concentration, amount of adsorbent and adsorption $\mathrm{pH}$ were optimized as well as different models were checked in kinetic and isotherm studies.

Effect of $\mathrm{pH}$. The effect of $\mathrm{pH}$ was investigated due to the structure and ionization degree of the MB dye can be influenced by $\mathrm{pH}$ value ${ }^{44}$. The $\mathrm{pKa}$ of $\mathrm{MB}$ is $3.8^{45}$, therefore, at $\mathrm{pH}$ values above this, the preponderant $\mathrm{MBs}$ are cationic. The effect of $\mathrm{pH}$ values was studied during $5 \mathrm{~min}$ using $0.005 \mathrm{~g}$ of the adsorbent (Fig. 12). At acidic $\mathrm{pH}$, the -OHs of mesoporous silica shell and magnetic core interact with $\mathrm{MBs}$ via $\mathrm{H}$-bonding. At basic $\mathrm{pH}, \mathrm{Si}-$ 


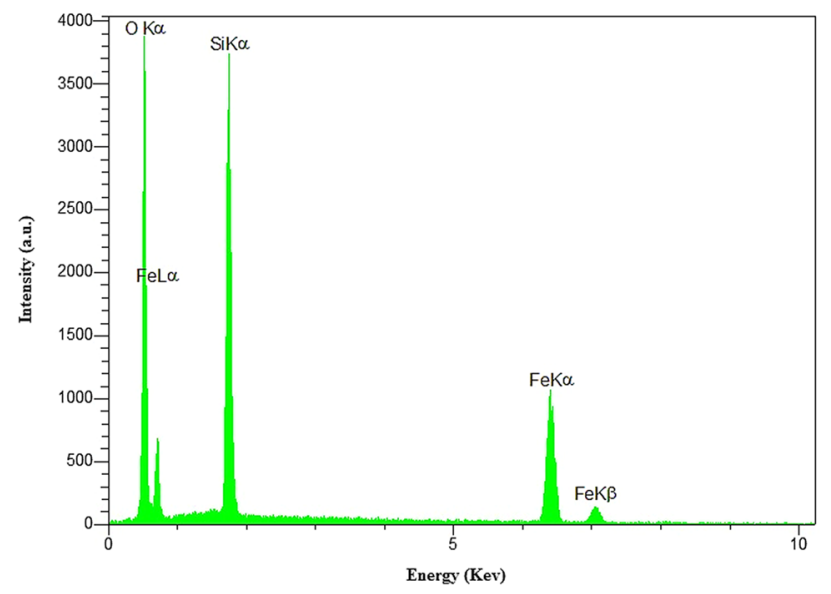

Figure 9. EDS analysis of $\mathrm{Fe}_{3} \mathrm{O}_{4} @ V$ Void@m. $\mathrm{SiO}_{2}$ nanomaterial before adsorption process.

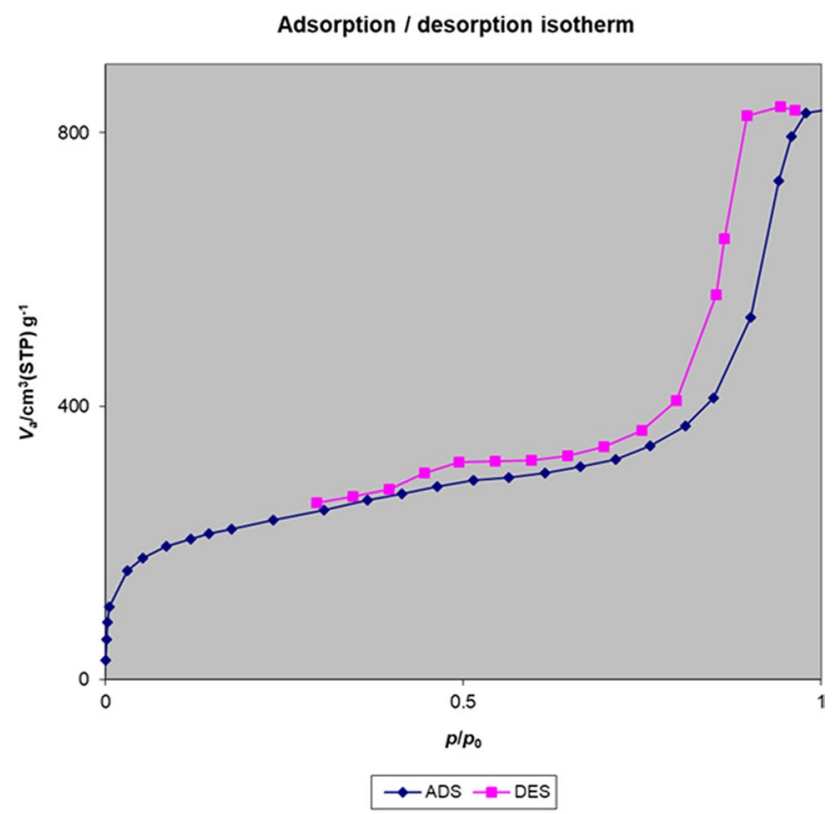

Figure 10. Nitrogen adsorption-desorption isotherm of the $\mathrm{Fe}_{3} \mathrm{O}_{4} @$ Void@m. $\mathrm{SiO}_{2}$ nanomaterial before adsorption process.

$\mathrm{O}-$ and $\mathrm{Fe}-\mathrm{O}-$ are the greater groups due to the deprotonation of $\mathrm{Si}-\mathrm{OH}$ and $\mathrm{Fe}-\mathrm{OH}$, respectively. These sites improve the electrostatic interaction between the cationic dye and the anionic charged surfaces (Fig. 13). Similar results have been reported for $\mathrm{MB}$ elimination using clay ${ }^{46,47}$ and activated coal ${ }^{48}$. Another important factor for this adsorption process is $\mathrm{H}$-bonding interactions between $\mathrm{N}$-sites of dye and $\mathrm{OH}$ sites of adsorbent. It is important to note that the aforementioned interactions can occur on both inner and outer surfaces of mesoporous silica shell and also on outer surface of magnetite cores ${ }^{49,50}$. According these findings, a suitable mechanism for this adsorption process is proposed in Fig. 13. According to this experiment, at pH 9.0 the best result was obtained. Therefore, this was used as optimum $\mathrm{pH}$ in the subsequent tests.

Effect of adsorbent dosage and dye concentration. In next step, the amounts of adsorbent and dye concentration were optimized (respectively, Figs. 14 and 15). It is clear that the adsorbent amount and the numbers of active positions on its surface affect the adsorption rate. By increasing the amount of adsorbent, the vacant and unoccupied positions are increased and thus the percentage of removal is increased. While, after this, there is a little change in the adsorption process. As shown in Fig. 14, the optimum amount of adsorbent is $0.005 \mathrm{~g}$ for $15 \mathrm{~mL}$ of $\mathrm{MB}$ aqueous solution (5 ppm) with $98.2 \%$ removal. This confirms high performance of the designed material in the MB removal. In the next, the effect of dye concentration using a constant amount $(0.005 \mathrm{~g})$ of adsorbent was studied. As shown in Fig. 15, by increasing the amount of MB concentration, the removal performance of a certain amount of $\mathrm{Fe}_{3} \mathrm{O}_{4} @$ Void@m.SiO $\mathrm{S}_{2}$ is reduced which it refers to disproportionate in amount of active sites 


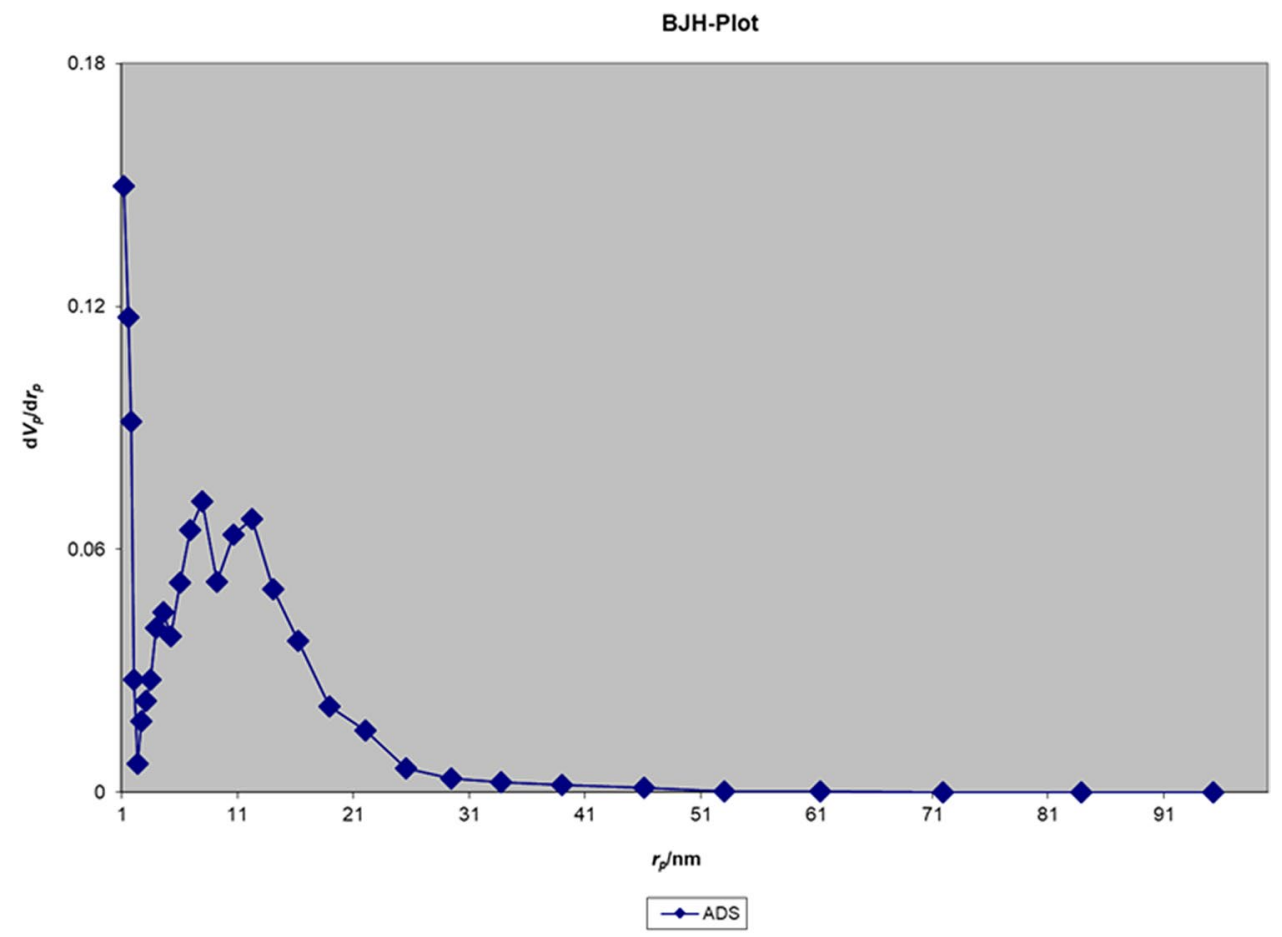

Figure 11. $\mathrm{BJH}$ pore size distribution isotherm of the $\mathrm{Fe}_{3} \mathrm{O}_{4} @$ Void@m.SiO $\mathrm{S}_{2}$ nanomaterial before adsorption process.

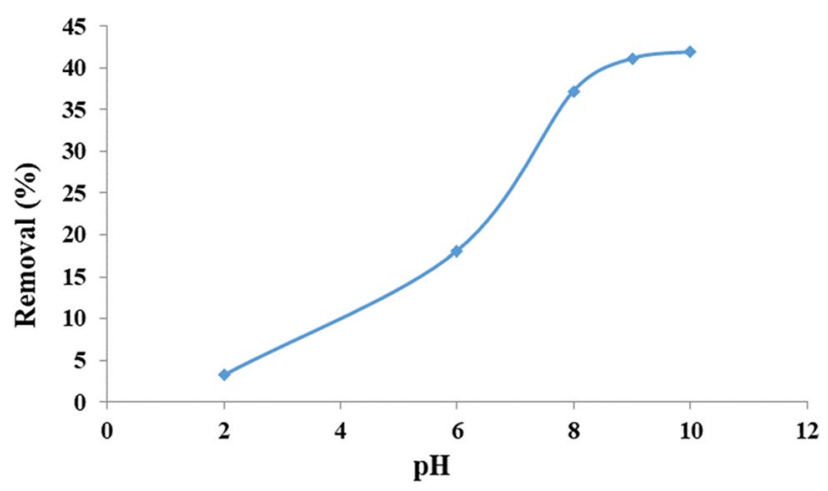

Figure 12. The effect of $\mathrm{pH}$ on $\mathrm{MB}$ adsorption.

and dye molecules. Accordingly, for $0.005 \mathrm{~g}$ of $\mathrm{Fe}_{3} \mathrm{O}_{4} @ \mathrm{Void} @ \mathrm{~m} . \mathrm{SiO}_{2}$ adsorbent, the optimum dye concentration was $5 \mathrm{ppm}$.

Effect of time. Figure 16 illustrates the time effect under optimum conditions. As seen, the rate of adsorption is high at first 3 min that can refer to adsorption by the outer surface of the shell. After that, this process is slowly increased with time. The latter adsorption can be happened on internal surface of the shell and also surface of the core. As shown, after 15 min the maximum adsorption is resulted.

Kinetics evaluation. To study the kinetics evaluation, the kinetic models of pseudo-first-order, second-order and Elovich were employed (Table 1). The pseudo-first-order model is as follows:

$$
\log \left(q_{e}-q_{t}\right)=\frac{\log q_{e}-k_{1} t}{2.303}
$$

where $\mathrm{q}_{\mathrm{t}}$ is the adsorbed dye at $\mathrm{t}$ time $(\mathrm{mg} / \mathrm{g}) ; \mathrm{q}_{\mathrm{e}}$ is adsorbed dye at equilibrium $(\mathrm{mg} / \mathrm{g})$ and $\mathrm{k}_{1}$ is the rate constant of adsorption $\left(\mathrm{min}^{-1}\right)$. The pseudo-second-order model is also as follows: 

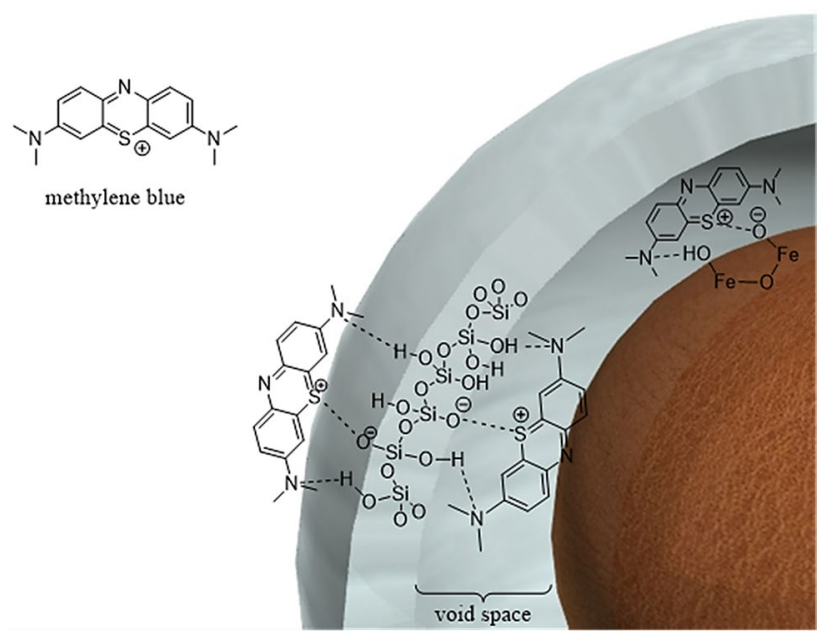

Figure 13. A suitable mechanism for $\mathrm{MB}$ adsorption using $\mathrm{Fe}_{3} \mathrm{O}_{4} @$ Void@m.SiO $\mathrm{S}_{2}$.

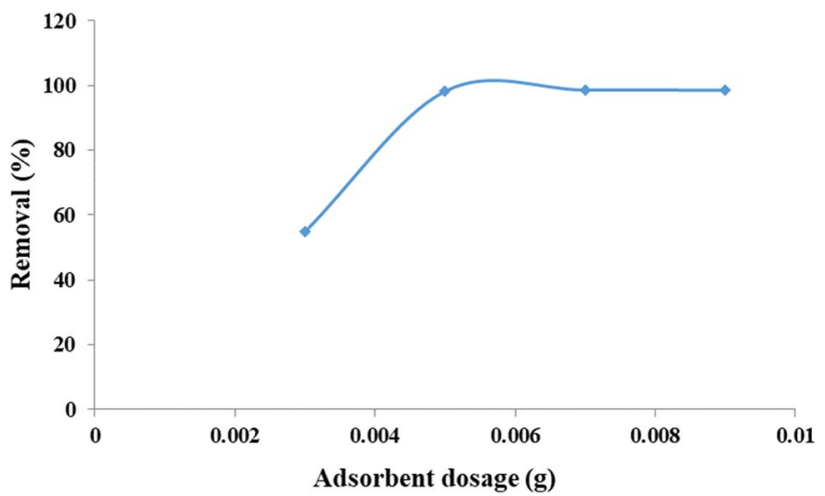

Figure 14. The effect of $\mathrm{Fe}_{3} \mathrm{O}_{4} @ V$ Void@m.SiO 2 amount on $\mathrm{MB}$ adsorption.

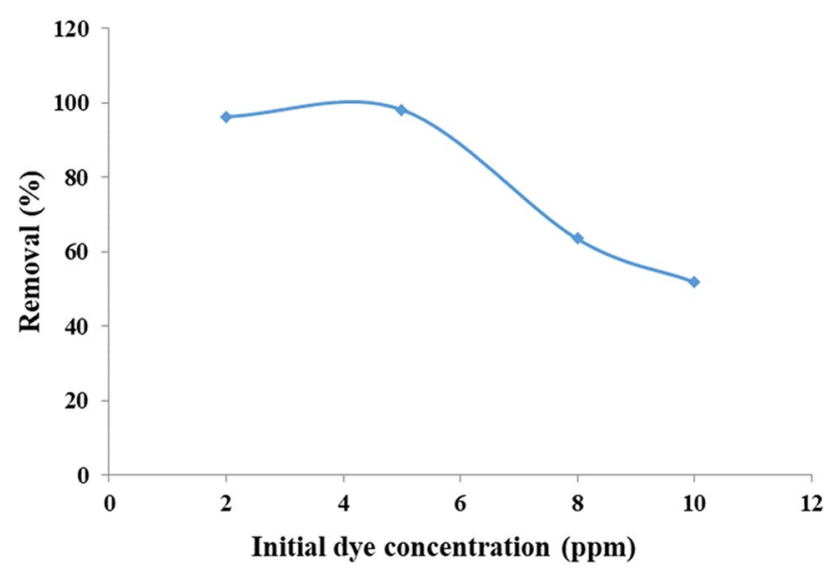

Figure 15. The effect of $\mathrm{MB}$ concentration using $0.005 \mathrm{~g}$ of adsorbent.

$$
\frac{t}{q_{t}}=\frac{1}{k_{2} q_{e}^{2}}+\frac{t}{q_{e}}
$$

the $\mathrm{q}_{\mathrm{e}}$ and $\mathrm{k}_{2}$ were obtained via the plot of $\frac{t}{q_{t}}$ versus $t$ (Fig. 17, Table 1). The Elovich equation is also as follows:

$$
q_{t}=1 / \beta \ln (\alpha \beta)+1 / \beta \ln (t)
$$




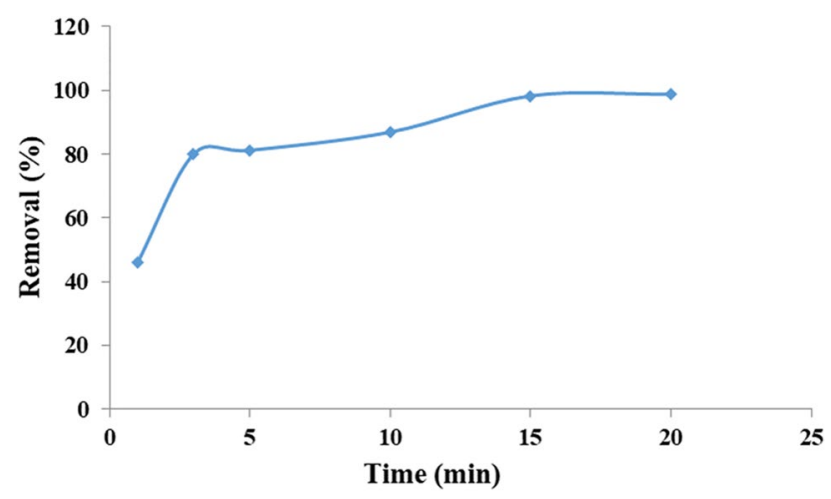

Figure 16. Effect of time.

\begin{tabular}{|l|l|l|}
\hline Model & Parameters & Adsorbent \\
\hline \multirow{4}{*}{ First-order kinetic } & & $\mathrm{Fe}_{3} \mathrm{O}_{4} @$ Void@m. $\mathrm{SiO}_{2}$ \\
\hline \multirow{4}{*}{ Second-order kinetic } & $\mathrm{k}_{1}$ & 0.093 \\
\cline { 2 - 3 } & $\mathrm{qe}($ calc) & 4.959 \\
\cline { 2 - 3 } & $\mathrm{R}^{2}$ & 0.808 \\
\hline \multirow{4}{*}{ Elovich } & $\mathrm{k}_{2}$ & 0.049 \\
\cline { 2 - 3 } & $\mathrm{q}_{\mathrm{e}}$ (calc) & 15.64 \\
\cline { 2 - 3 } & $\mathrm{R}^{2}$ & 0.997 \\
\hline & $\mathrm{B}$ & 0.406 \\
\cline { 2 - 3 } & $\mathrm{A}$ & 59.943 \\
\cline { 2 - 3 } & $\mathrm{R}^{2}$ & 0.912 \\
\hline
\end{tabular}

Table 1. Kinetic parameters for MB adsorption using $\mathrm{Fe}_{3} \mathrm{O}_{4} @ V$ Void@m. $\mathrm{SiO}_{2}$.

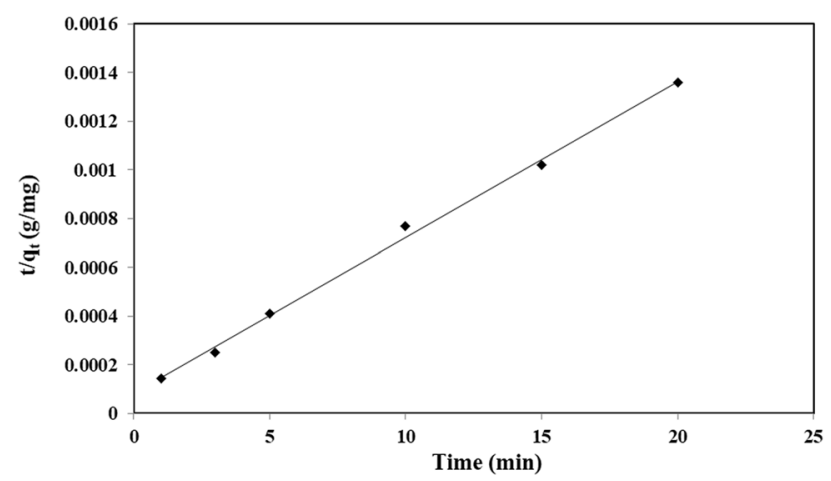

Figure 17. The pseudo-second-order plot of $\mathrm{MB}$ adsorption using $\mathrm{Fe}_{3} \mathrm{O}_{4} @$ Void@m.SiO ${ }_{2}$.

As shown in Table 1 and Fig. 17, the pseudo-second-order model with a linear regression correlation coefficient $\left(R^{2}\right)$ value of 0.997 is completely applicable for the process.

Isotherm study. To determine the maximum capacity of sorption, the Langmuir, Freundlich and Temkin isotherm models were employed. The Langmuir model is as follows:

$$
q_{e}=q_{m} \frac{K_{L} C_{e}}{1+K_{L} C_{e}}
$$

where $\mathrm{q}_{\mathrm{e}}$ is the equilibrium concentration of dye, $\mathrm{q}_{\mathrm{m}}$ is the maximum dye uptake and $\mathrm{K}_{\mathrm{L}}$ is Langmuir constant. These are determined by linearizing of Eq. (6) as shown in Eq. (7), 


\begin{tabular}{|l|l|l|}
\hline Isotherm & Parameters & Adsorbent \\
\hline & & $\mathrm{Fe}_{3} \mathrm{O}_{4} @$ Void@m. $\mathrm{SiO}_{2}$ \\
\hline \multirow{4}{*}{ Langmuir } & $\mathrm{Q}_{\mathrm{m}}(\mathrm{mg} / \mathrm{g})$ & 163.934 \\
\cline { 2 - 3 } & $\mathrm{K}_{\mathrm{a}}(\mathrm{L} / \mathrm{mg})$ & 0.095 \\
\cline { 2 - 3 } & $\mathrm{R}^{2}$ & 0.996 \\
\hline \multirow{4}{*}{ Freundlich } & $1 / \mathrm{n}$ & 0.130 \\
\cline { 2 - 3 } & $\mathrm{K}_{\mathrm{F}}(\mathrm{L} / \mathrm{mg})$ & 349.945 \\
\cline { 2 - 3 } & $\mathrm{R}^{2}$ & 0.379 \\
\hline \multirow{4}{*}{ Tempkin } & $\mathrm{B}_{1}$ & 1.287 \\
\cline { 2 - 3 } & $\mathrm{K}_{\mathrm{T}}(\mathrm{L} / \mathrm{mg})$ & $34,166.468$ \\
\cline { 2 - 3 } & $\mathrm{R}^{2}$ & 0.393 \\
\hline
\end{tabular}

Table 2. Isotherm parameters and $\mathrm{R}^{2}$ amounts obtained for the $\mathrm{MB}$ adsorption using $\mathrm{Fe}_{3} \mathrm{O}_{4} @$ Void@m.SiO .

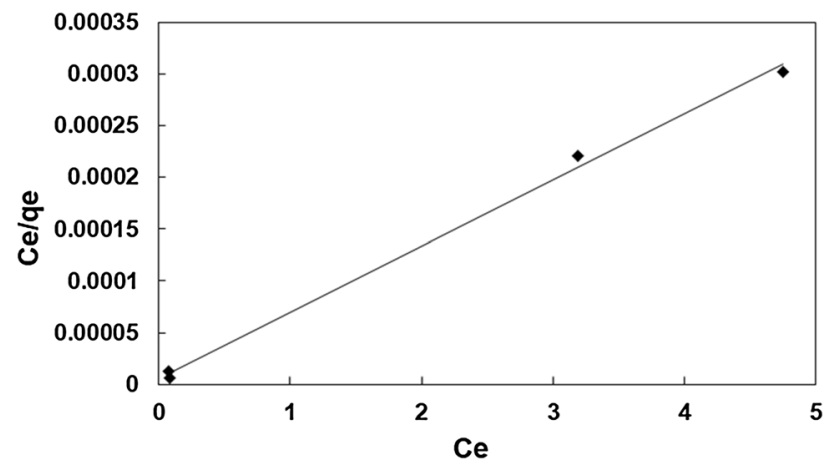

Figure 18. The Langmuir plot of $\mathrm{MB}$ adsorption by using $\mathrm{Fe}_{3} \mathrm{O}_{4} @$ Void@m.SiO ${ }_{2}$.

$$
\frac{C_{e}}{q_{e}}=\frac{1}{K_{L} Q_{m}}+\frac{C_{e}}{Q_{m}}
$$

The Freundlich model is also as follows:

$$
q_{e}=K_{F} C_{e}^{1 / n}
$$

The linear form of above equation is Eq. (9) in which $\mathrm{K}_{\mathrm{f}}$ and $\mathrm{n}$ are Freundlich constants

$$
\log \left(q_{e}\right)=\log \left(K_{F}\right)+\frac{1}{n} \log \left(C_{e}\right)
$$

The other isotherm model is Temkin with a linear form as follows:

$$
q_{e}=B_{T} \ln K_{T}+B_{T} \ln C_{e}
$$

As shown in Table 2 and Fig. 18, the Langmuir model with an $\mathrm{R}^{2}>0.99$ is the best isotherm for the process.

Thermodynamic study. Thermodynamic parameters $\left(\Delta \mathrm{G}^{0}, \Delta \mathrm{H}^{0}\right.$ and $\left.\Delta \mathrm{S}^{0}\right)$ were calculated by using following equations ${ }^{51}$ :

$$
\begin{gathered}
K_{c}=\frac{q_{e}}{C_{e}} \\
\Delta G^{0}=-R T \ln K_{c} \\
\Delta G^{0}=\Delta H^{0}-T \Delta S^{0} \\
\ln K_{c}=\frac{\Delta S^{0}}{R}-\frac{\Delta H^{0}}{R T}
\end{gathered}
$$

These parameters are listed in Table 3. The plot of $\ln \mathrm{K}_{\mathrm{c}}$ versus $1 / \mathrm{T}$ is illustrated in Fig. 19. As shown, a satisfactory adsorption is resulted at RT and by increasing the temperature from 25 to $55^{\circ} \mathrm{C}$, a slight decrease in 


\begin{tabular}{|c|c|c|c|c|}
\hline Temperature (K) & $\Delta \mathrm{G}^{0}(\mathrm{~kJ} / \mathrm{mol})$ & $\Delta \mathrm{H}^{0}(\mathrm{~kJ} / \mathrm{mol})$ & $\Delta S^{0}(\mathrm{~J} / \mathrm{mol} \mathrm{K})$ & $\mathbf{R}^{2}$ \\
\hline 298 & -12.79 & \multirow{4}{*}{-43.94} & \multirow{4}{*}{-104.65} & \multirow{4}{*}{0.999} \\
\hline 308 & -11.65 & & & \\
\hline 318 & -10.65 & & & \\
\hline 328 & -9.64 & & & \\
\hline
\end{tabular}

Table 3. Thermodynamic parameters of $\mathrm{MB}$ adsorption using $\mathrm{Fe}_{3} \mathrm{O}_{4} @ \mathrm{Void} @ \mathrm{~m} \cdot \mathrm{SiO}_{2}$.

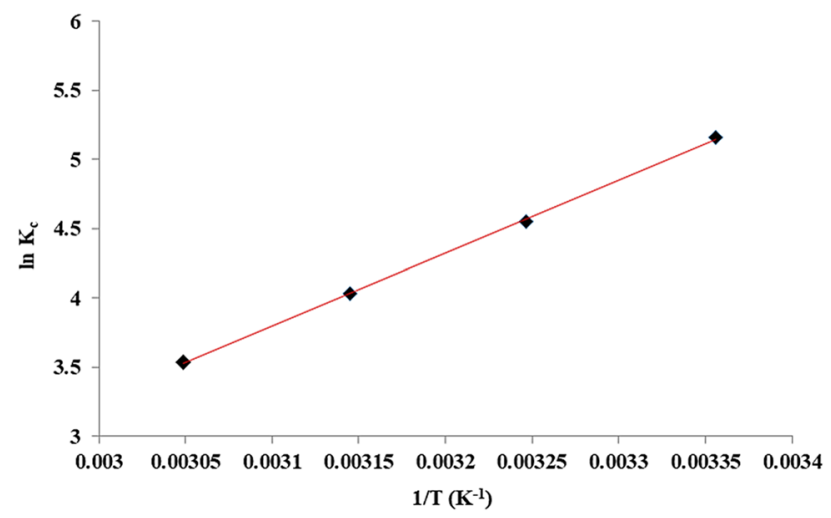

Figure 19. The plot of $\ln \mathrm{K}_{\mathrm{c}}$ versus $1 / \mathrm{T}$.

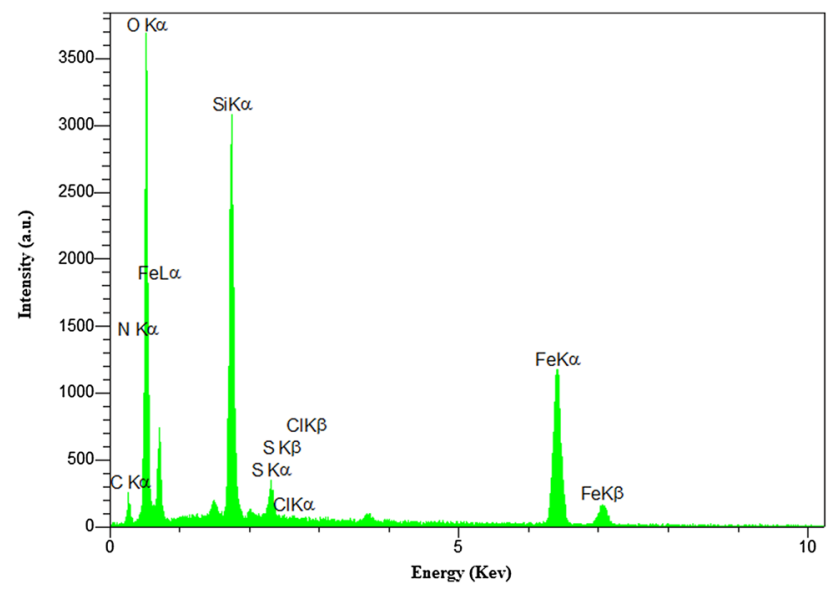

Figure 20. The EDS analysis of $\mathrm{Fe}_{3} \mathrm{O}_{4} @ V$ Void@m.SiO $\mathrm{S}_{2}$ nanomaterial after $\mathrm{MB}$ adsorption.

$\mathrm{MB}$ adsorption is observed indicating the process is exothermic. This was also confirmed by the negative $\Delta \mathrm{H}^{\circ}$. The negative amount of $\Delta \mathrm{G}^{0}$ confirms that the $\mathrm{MB}$ adsorption on $\mathrm{Fe}_{3} \mathrm{O}_{4} @$ Void@m. $\mathrm{SiO}_{2}$ is achievable and spontaneous. The negative $\Delta S^{\circ}$ also suggests a decrease in randomness at solid/solution interface ${ }^{52}$. Moreover, the amounts of $\Delta \mathrm{H}^{0}$ and $\Delta \mathrm{G}^{0}$ successfully indicate that $\mathrm{MB}$ molecules are both physically and chemically adsorbed into/onto adsorbent material.

EDS spectrum. To investigate the successful adsorption of $\mathrm{MB}$ molecules into/onto $\mathrm{Fe}_{3} \mathrm{O}_{4} @ \mathrm{Void} @ \mathrm{~m} . \mathrm{SiO}_{2}$, the EDS analysis after adsorption process was performed (Fig. 20). As shown, the existence of new peaks of carbon, nitrogen, sulfur and chlorine in this spectrum confirms successful adsorption of MB molecules into/onto material.

Nitrogen adsorption-desorption and BJH pore size distribution isotherms. The nitrogen adsorption-desorption analysis of the $\mathrm{Fe}_{3} \mathrm{O}_{4} @$ Void@m.SiO $\mathrm{S}_{2}$ nanomaterial after adsorption of $\mathrm{MB}$ was performed (Fig. 21). According to this analysis, the BET surface area and total pore volume of the $\mathrm{Fe}_{3} \mathrm{O}_{4} @$ Void@m. $\mathrm{SiO}_{2}$ nanomaterial after adsorption process were reduced to $142.32 \mathrm{~m}^{2} / \mathrm{g}$ and $0.35 \mathrm{~cm}^{3} / \mathrm{g}$, respectively. The $\mathrm{BJH}$ pore size distribution isotherm after adsorption process also showed that the sizes of shell pores and void space between yolk and shell are 5.1 and 7.9, respectively (Fig. 22). Moreover, as shown in the Figs. 21 and 22, after the adsorption process the inten- 


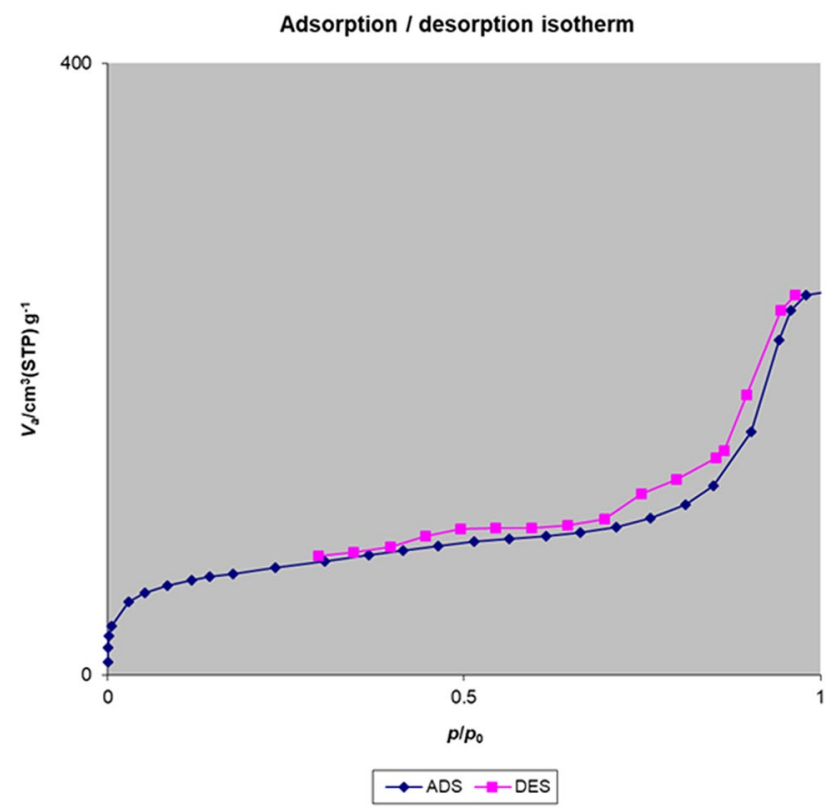

Figure 21. Nitrogen adsorption-desorption isotherm of the $\mathrm{Fe}_{3} \mathrm{O}_{4} @$ Void@m.SiO $\mathrm{S}_{2}$ nanomaterial after adsorption process.

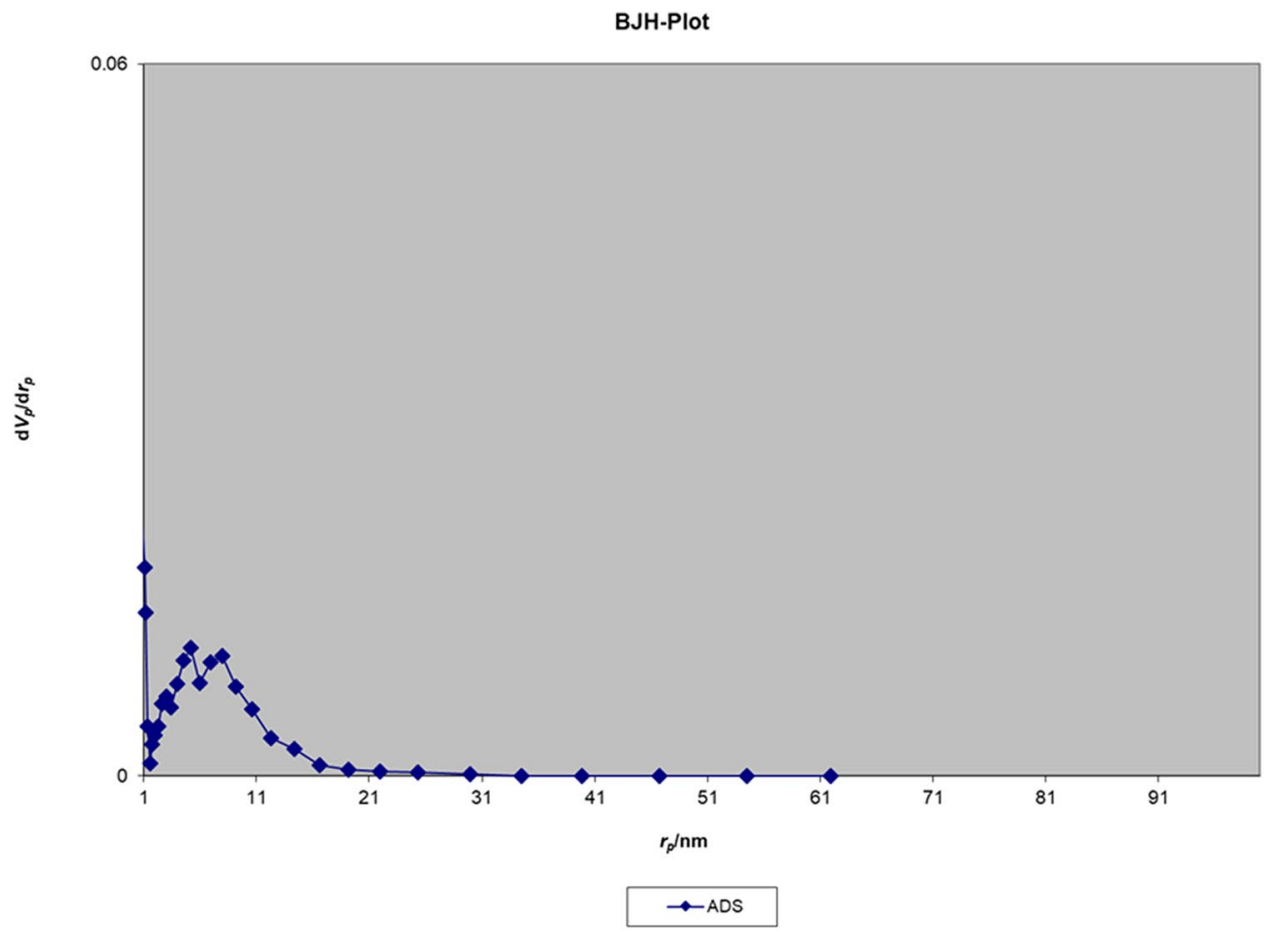

Figure 22. $\mathrm{BJH}$ pore size distribution isotherm of the $\mathrm{Fe}_{3} \mathrm{O}_{4} @$ Void@m.SiO $\mathrm{S}_{2}$ nanomaterial after adsorption process.

sity of both adsorption-desorption and $\mathrm{BJH}$ isotherms are reduced in comparison to the fresh material. These observations confirm that both cavities and pores of the adsorbent are occupied by MB molecules.

Recoverability and reusability studies. In next step, the recoverability and reusability of the $\mathrm{Fe}_{3} \mathrm{O}_{4} @$ Void@m. $\mathrm{SiO}_{2}$ were investigated. To do this, the adsorbed MB molecules on $\mathrm{Fe}_{3} \mathrm{O}_{4} @$ Void@m. $\mathrm{SiO}_{2}$ were desorbed by acidic ethanol ( $\mathrm{pH}$ 2). Then, the adsorbent was recovered and reused under the same conditions as the first run. As 


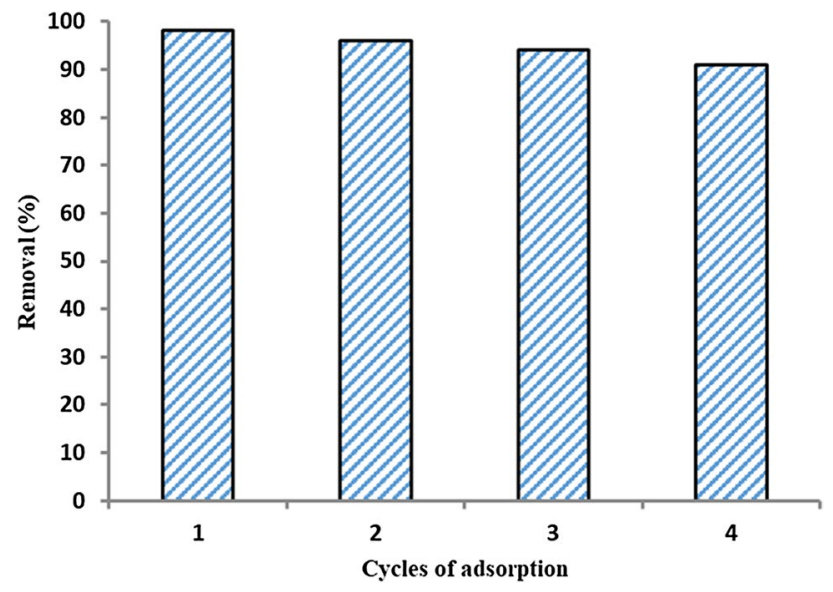

Figure 23. Recoverability and reusability of $\mathrm{Fe}_{3} \mathrm{O}_{4} @ \mathrm{Void} @ \mathrm{~m} \cdot \mathrm{SiO}_{2}$.

\begin{tabular}{|c|c|c|c|c|c|c|}
\hline Entry & Adsorbent & Conditions & Adsorption efficiency (\%) & Adsorption capacity $(\mathrm{mg} / \mathrm{g})$ & Recovery times & Ref \\
\hline 1 & $\begin{array}{l}\text { Graphene oxide/calcium alginate } \\
\text { composite }\end{array}$ & $\begin{array}{l}3 \mathrm{~h}, 25^{\circ} \mathrm{C}, 100 \mathrm{~mL} \text { of } 30-80 \mathrm{mg} / \mathrm{L} \text { of } \\
\mathrm{MB} \text { solution, } 0.05 \mathrm{~g} \text { adsorbent }\end{array}$ & $88.6-92.7$ & 181.81 & - & 53 \\
\hline 2 & Activated carbon & $\begin{array}{l}1 \mathrm{~h}, 25^{\circ} \mathrm{C}, 10 \mathrm{~mL} \text { of } 250-500- \\
750 \mathrm{mg} / \mathrm{L} \text { of MB solution, } 0.05 \mathrm{~g} \\
\text { adsorbent }\end{array}$ & - & 270.3 & - & 54 \\
\hline 3 & $\begin{array}{l}\text { Polyaniline nanotubes base/silica } \\
\text { composite }\end{array}$ & $\begin{array}{l}1 \mathrm{~h}, 25^{\circ} \mathrm{C}, 100 \mathrm{~mL} \text { of } 3.1 \mathrm{mg} / \mathrm{L} \text { of } \mathrm{MB} \\
\text { solution, } 0.05 \mathrm{~g} \text { adsorbent }\end{array}$ & - & $0.61-5.38$ & - & 55 \\
\hline 4 & Iron terephthalate (MOF-235) & $\begin{array}{l}1 \mathrm{~h}, 25^{\circ} \mathrm{C}, 50 \mathrm{~mL} \text { of } 3.1 \mathrm{mg} / \mathrm{L} \text { of } \mathrm{MB} \\
\text { solution, } 0.05 \mathrm{~g} \text { adsorbent }\end{array}$ & - & 477 & - & 56 \\
\hline 5 & $\begin{array}{l}\text { Nanocomposite of hydrolyzed poly- } \\
\text { acrylamide grafted xanthan gum and } \\
\text { incorporated nanosilica }\end{array}$ & $\begin{array}{l}20 \mathrm{~min}, 50^{\circ} \mathrm{C}, 25 \mathrm{~mL} \text { of } 30 \mathrm{mg} / \mathrm{Lof} \\
\text { MB solution, } 0.03 \mathrm{~g} \text { adsorbent }\end{array}$ & 99.4 & 497.5 & - & 57 \\
\hline 6 & $\begin{array}{l}\mathrm{Fe}_{3} \mathrm{O}_{4} \text {-graphene@mesoporous } \mathrm{SiO}_{2} \\
\text { nanocomposites }\end{array}$ & $\begin{array}{l}15 \mathrm{~min}, 25^{\circ} \mathrm{C}, 25 \mathrm{~mL} \text { of } 10 \mathrm{mg} / \mathrm{Lof} \\
\text { MB solution, } 0.01 \mathrm{~g} \text { adsorbent }\end{array}$ & 100 & $0.98-102.2$ & - & 58 \\
\hline 7 & $\begin{array}{l}\text { Yolk-shell tubular } \mathrm{Fe}_{2} \mathrm{O}_{3} @ \text { magne- } \\
\text { sium silicate }\end{array}$ & $\begin{array}{l}15 \mathrm{~h}, 25^{\circ} \mathrm{C}, 10 \mathrm{~mL} \text { of } 50 \mathrm{mg} / \mathrm{L} \text { of } \mathrm{MB} \\
\text { solution, } 0.01 \mathrm{~g} \text { adsorbent }\end{array}$ & 94 & 188 & - & 59 \\
\hline 8 & $\begin{array}{l}\mathrm{Fe}_{3} \mathrm{O}_{4} @ \mathrm{SiO}_{2} \text { composite (adsorption- } \\
\text { photodegradation) }\end{array}$ & $\begin{array}{l}5 \mathrm{~min}, 25^{\circ} \mathrm{C}, 10 \mathrm{~mL} \text { of } 10 \mathrm{mg} / \mathrm{L} \text { of } \\
\text { MB solution, } 0.01 \mathrm{~g} \text { adsorbent }\end{array}$ & 99 & 33.12 & 5 & 60 \\
\hline 9 & $\begin{array}{l}\text { Yolk shell magnetic } \mathrm{Fe}_{3} \mathrm{O}_{4} @ \text { hierar- } \\
\text { chical hollow silica nanomaterials }\end{array}$ & $\begin{array}{l}1 \mathrm{~h}, 25^{\circ} \mathrm{C}, 50 \mathrm{~mL} \text { of } 40 \mathrm{mg} / \mathrm{L} \text { of } \mathrm{MB} \\
\text { solution, } 0.05 \mathrm{~g} \text { adsorbent }\end{array}$ & 92 & 71.45 & 5 & 18 \\
\hline 10 & $\begin{array}{l}\mathrm{Fe}_{3} \mathrm{O}_{4} @ \text { Void@m.SiO } \\
\text { nanomaterial yolk-shell }\end{array}$ & $\begin{array}{l}15 \mathrm{~min}, 25^{\circ} \mathrm{C}, 15 \mathrm{~mL} \text { of } 5 \mathrm{mg} / \mathrm{L} \text { of } \\
\text { MB solution, } 0.005 \mathrm{~g} \text { adsorbent }\end{array}$ & 98.2 & 163.93 & 3 & This work \\
\hline
\end{tabular}

Table 4. A comparison study between present adsorbent and previously reported adsorbents in the MB removal.

Fig. 23 shown, there is an insignificant decrease in adsorption ability of adsorbent after three cycles indicating the high stability and efficiency of designed $\mathrm{Fe}_{3} \mathrm{O}_{4} @$ Void@m.SiO $\mathrm{S}_{2}$ for $\mathrm{MB}$ removal.

Comparison study. Next, the adsorption efficiency of our designed $\mathrm{Fe}_{3} \mathrm{O}_{4} @$ Void@m.SiO $\mathrm{S}_{2}$ nanomaterial was compared with some reported adsorbents in $\mathrm{MB}$ adsorption (Table 4). As shown, in the most of previous studies the adsorbent is not recovered and also in some cases higher temperature than RT is needed for absorption. Moreover, the time required for absorption in most of former reports is high. These findings successfully confirm higher tendency and excellent capacity of the $\mathrm{Fe}_{3} \mathrm{O}_{4} @$ Void@m.SiO $\mathrm{S}_{2}$ for adsorption of $\mathrm{MB}$ molecules in comparison to previous adsorbents.

\section{Conclusion}

In summary, a magnetic yolk-shell structured nanomaterial with mesoporous shell $\left(\mathrm{Fe}_{3} \mathrm{O}_{4} @ \mathrm{Void} @ \mathrm{~m} . \mathrm{SiO}_{2}\right)$ was prepared, characterized and used as an effective adsorbent for the removal of $\mathrm{MB}$ dye from aqueous solution. The adsorption study showed that the designed material is so efficient with high removal capacity. Optimum conditions to achieve maximum removal of $98.2 \%$ for adsorption process were $0.005 \mathrm{~g}$ of adsorbent, $\mathrm{pH} 9$ and $15 \mathrm{~min}$ for $15 \mathrm{~mL}$ of $5 \mathrm{mg} / \mathrm{mL} \mathrm{MB}$ solution. The kinetic and isotherm studies of adsorption process were investigated and different models were evaluated for the equilibrium data. The results showed that the Langmuir isotherm model and pseudo-second-order kinetic are successfully fitted. The maximum adsorption capacity of the material was 
$163.93 \mathrm{mg} / \mathrm{g}$. The comparison study illustrated that the present adsorbent is much more efficient than previously reported adsorbents in the removal of MB dye.

Received: 24 September 2021; Accepted: 22 November 2021

Published online: 01 December 2021

\section{References}

1. Kamata, K., Lu, Y. \& Xia, Y. Synthesis and characterization of monodispersed core-shell spherical colloids with movable cores. J. Am. Chem. Soc. 125, 2384-2385 (2003).

2. Kim, M., Sohn, K., Na, H. B. \& Hyeon, T. Synthesis of nanorattles composed of gold nanoparticles encapsulated in mesoporous carbon and polymer shells. Nano Lett. 2, 1383-1387 (2002).

3. Guo, C.-W., Cao, Y., Xie, S.-H., Dai, W.-L. \& Fan, K.-N. Fabrication of mesoporous core-shell structured titania microspheres with hollow interiors. Chem. Commun., 700-701 (2003).

4. Wang, W., Dahl, M. \& Yin, Y. Hollow nanocrystals through the nanoscale Kirkendall effect. Chem. Mater. 25, 1179-1189 (2013).

5. Fang, X. et al. Hollow mesoporous aluminosilica spheres with perpendicular pore channels as catalytic nanoreactors. ACS Nano 6, 4434-4444 (2012).

6. Liu, J. et al. Yolk-shell hybrid materials with a periodic mesoporous organosilica shell: Ideal nanoreactors for selective alcohol oxidation. Adv. Funct. Mater. 22, 591-599 (2012).

7. Cipolatti, E. P. et al. Nanomaterials for biocatalyst immobilization-State of the art and future trends. RSC Adv. 6, 104675-104692 (2016).

8. Ni, W., Wang, Y. \& Xu, R. Formation of Sn@ C yolk-shell nanospheres and core-sheath nanowires for highly reversible lithium storage. Part. Part. Syst. Charact. 30, 873-880 (2013).

9. Song, H., Cui, H. \& Wang, C. Abnormal cyclibility in Ni@ graphene core-shell and yolk-shell nanostructures for lithium ion battery anodes. ACS Appl. Mater. Interfaces 6, 13765-13769 (2014).

10. Li, X. et al. Design of Au@ ZnO yolk-shell nanospheres with enhanced gas sensing properties. ACS Appl. Mater. Interfaces 6, 18661-18667 (2014).

11. Rai, P. et al. Design of highly sensitive and selective Au@ NiO yolk-shell nanoreactors for gas sensor applications. Nanoscale 6, 8292-8299 (2014).

12. Wang, S., Zhang, M. \& Zhang, W. Yolk- shell catalyst of single Au nanoparticle encapsulated within hollow mesoporous silica microspheres. ACS Catal. 1, 207-211 (2011).

13. Zhang, J., Li, B. \& Yang, W. Synthesis and photocatalytic performance of novel hierarchical hollow silica sphere supported $\mathrm{TiO}_{2}$ nanoparticles. Mater. Lett. 117, 252-255 (2014).

14. Norouzi, M. \& Elhamifar, D. Magnetic yolk-shell structured methylene and propylamine based mesoporous organosilica nanocomposite: A highly recoverable and durable nanocatalyst with improved efficiency. Colloids Surf. A Physicochem. Eng. Asp. 615, 126226 (2021).

15. Mirbagheri, R., Elhamifar, D. \& Hajati, S. Ru-containing magnetic yolk-shell structured nanocomposite: A powerful, recoverable and highly durable nanocatalyst. RSC Adv. 11, 10243-10252 (2021).

16. Shaker, M. \& Elhamifar, D. Cu-containing magnetic yolk-shell structured ionic liquid-based organosilica nanocomposite: A powerful catalyst with improved activity. Compos. Commun. 24, 100608 (2021).

17. Fan, H., Lei, Z., Pan, J. H. \& Zhao, X. Sol-gel synthesis, microstructure and adsorption properties of hollow silica spheres. Mater. Lett. 65, 1811-1814 (2011)

18. Zhang, J., Li, B., Yang, W. \& Liu, J. Synthesis of magnetic Fe3O4@ hierarchical hollow silica nanospheres for efficient removal of methylene blue from aqueous solutions. Ind. Eng. Chem. Res. 53, 10629-10636 (2014).

19. Liu, J. et al. Uniform yolk-shell Sn 4 P 3@ C nanospheres as high-capacity and cycle-stable anode materials for sodium-ion batteries. Energy Environ. Sci. 8, 3531-3538 (2015).

20. Cho, J. S. \& Kang, Y. C. Nanofibers comprising yolk-shell Sn@ void@ SnO/SnO 2 and hollow $\mathrm{SnO} / \mathrm{SnO}_{2}$ and $\mathrm{SnO}_{2}$ nanospheres via the Kirkendall diffusion effect and their electrochemical properties. Small 11, 4673-4681 (2015).

21. Li, S. et al. High-rate aluminium yolk-shell nanoparticle anode for Li-ion battery with long cycle life and ultrahigh capacity. Nat. Commun. 6, 1-7 (2015).

22. Evangelista, V. et al. Highly active Au-CeO2@ ZrO2 yolk-shell nanoreactors for the reduction of 4-nitrophenol to 4-aminophenol. Appl. Catal. B 166, 518-528 (2015).

23. Du, X. \& He, J. Spherical silica micro/nanomaterials with hierarchical structures: Synthesis and applications. Nanoscale 3, 3984$4002(2011)$.

24. Li, Z. et al. Measurement of uptake and release capacities of mesoporous silica nanoparticles enabled by nanovalve gates. J. Phys. Chem. C 115, 19496-19506 (2011).

25. Purbia, R. \& Paria, S. Yolk/shell nanoparticles: Classifications, synthesis, properties, and applications. Nanoscale 7, 19789-19873 (2015).

26. Wang, Q., Liu, Y. \& Yan, H. Mechanism of a self-templating synthesis of monodispersed hollow silica nanospheres with tunable size and shell thickness. Chem. Commun., 2339-2341 (2007).

27. Zoldesi, C. I., van Walree, C. A. \& Imhof, A. Deformable hollow hybrid silica/siloxane colloids by emulsion templating. Langmuir 22, 4343-4352 (2006).

28. Park, J.-I. \& Cheon, J. Synthesis of "solid solution" and "core-shell" type cobalt-platinum magnetic nanoparticles via transmetalation reactions. J. Am. Chem. Soc. 123, 5743-5746 (2001).

29. Piao, Y. et al. Wrap-bake-peel process for nanostructural transformation from $\beta$-FeOOH nanorods to biocompatible iron oxide nanocapsules. Nat. Mater. 7, 242-247 (2008).

30. Lee, J.-H. et al. Artificially engineered magnetic nanoparticles for ultra-sensitive molecular imaging. Nat. Med. 13, 95-99 (2007).

31. Wu, X. et al. Immunofluorescent labeling of cancer marker Her2 and other cellular targets with semiconductor quantum dots. Nat. Biotechnol. 21, 41-46 (2003).

32. Dubertret, B. et al. In vivo imaging of quantum dots encapsulated in phospholipid micelles. Science 298, 1759-1762 (2002).

33. Elhamifar, D., Mofatehnia, P. \& Faal, M. Magnetic nanoparticles supported Schiff-base/copper complex: An efficient nanocatalyst for preparation of biologically active 3, 4-dihydropyrimidinones. J. Colloid Interface Sci. 504, 268-275 (2017).

34. Elhamifar, D., Ramazani, Z., Norouzi, M. \& Mirbagheri, R. Magnetic iron oxide/phenylsulfonic acid: A novel, efficient and recoverable nanocatalyst for green synthesis of tetrahydrobenzo [b] pyrans under ultrasonic conditions. J. Colloid Interface Sci. 511, 392-401 (2018).

35. Mousavi, F., Elhamifar, D. \& Kargar, S. Copper/IL-containing magnetic nanoporous MCM-41: A powerful and highly stable nanocatalyst. Surf. Interfaces 25, 101225 (2021).

36. Dutta, K., Mukhopadhyay, S., Bhattacharjee, S. \& Chaudhuri, B. Chemical oxidation of methylene blue using a Fenton-like reaction. J. Hazard. Mater. 84, 57-71 (2001). 
37. Lachheb, H. et al. Photocatalytic degradation of various types of dyes (Alizarin S, Crocein Orange G, Methyl Red, Congo Red, Methylene Blue) in water by UV-irradiated titania. Appl. Catal. B 39, 75-90 (2002).

38. Oliveira, L. C., Petkowicz, D. I., Smaniotto, A. \& Pergher, S. B. Magnetic zeolites: A new adsorbent for removal of metallic contaminants from water. Water Res. 38, 3699-3704 (2004).

39. Peng, X., Luan, Z., Di, Z., Zhang, Z. \& Zhu, C. Carbon nanotubes-iron oxides magnetic composites as adsorbent for removal of $\mathrm{Pb}$ (II) and $\mathrm{Cu}$ (II) from water. Carbon 43, 880-883 (2005).

40. Fei, P., Zhong, M., Lei, Z. \& Su, B. One-pot solvothermal synthesized enhanced magnetic zinc ferrite-reduced graphene oxide composite material as adsorbent for methylene blue removal. Mater. Lett. 108, 72-74 (2013).

41. Jiang, T., Liang, Y.-D., He, Y.-J. \& Wang, Q. Activated carbon/ $\mathrm{NiFe}_{2} \mathrm{O}_{4}$ magnetic composite: A magnetic adsorbent for the adsorption of methyl orange. J. Environ. Chem. Eng. 3, 1740-1751 (2015).

42. Mirbagheri, R., Elhamifar, D. \& Norouzi, M. Propylamine-containing magnetic ethyl-based organosilica with a core-shell structure: An efficient and highly stable nanocatalyst. New J. Chem. 42, 10741-10750 (2018).

43. Dai, J. et al. Yolk-shell $\mathrm{Fe}_{3} \mathrm{O}_{4} @ \mathrm{SiO}_{2} @ \mathrm{PMO}$ : Amphiphilic magnetic nanocomposites as an adsorbent and a catalyst with high efficiency and recyclability. Green Chem. 19, 1336-1344 (2017).

44. Wang, L. et al. Adsorption of $\mathrm{Pb}$ (II) on activated carbon prepared from Polygonum orientale Linn.: Kinetics, isotherms, $\mathrm{pH}$, and ionic strength studies. Bioresour. Technol. 101, 5808-5814 (2010).

45. Sousa, H. R. et al. Evaluation of methylene blue removal by plasma activated palygorskites. J. Mater. Res. Technol. 8, 5432-5442 (2019).

46. Şahin, Ö., Kaya, M. \& Saka, C. Plasma-surface modification on bentonite clay to improve the performance of adsorption of methylene blue. Appl. Clay Sci. 116, 46-53 (2015).

47. Adeyemo, A. A., Adeoye, I. O. \& Bello, O. S. Adsorption of dyes using different types of clay: A review. Appl. Water Sci. 7, 543-568 (2017).

48. El Qada, E. N., Allen, S. J. \& Walker, G. M. Adsorption of basic dyes from aqueous solution onto activated carbons. Chem. Eng. J. 135, 174-184 (2008).

49. Chandrasekhar, S. \& Pramada, P. Rice husk ash as an adsorbent for methylene blue-Effect of ashing temperature. Adsorption 12, 27-43 (2006).

50. Hamdaoui, O. Batch study of liquid-phase adsorption of methylene blue using cedar sawdust and crushed brick. J. Hazard. Mater. 135, 264-273 (2006).

51. You, L., Wu, Z., Kim, T. \& Lee, K. Kinetics and thermodynamics of bromophenol blue adsorption by a mesoporous hybrid gel derived from tetraethoxysilane and bis (trimethoxysilyl) hexane. J. Colloid Interface Sci. 300, 526-535 (2006).

52. Alkan, M., Demirbaş, Ö. \& Doğan, M. Adsorption kinetics and thermodynamics of an anionic dye onto sepiolite. Microporous Mesoporous Mater. 101, 388-396 (2007).

53. Li, Y. et al. Methylene blue adsorption on graphene oxide/calcium alginate composites. Carbohydr. Polym. 95, 501-507 (2013).

54. Dural, M. U., Cavas, L., Papageorgiou, S. K. \& Katsaros, F. K. Methylene blue adsorption on activated carbon prepared from Posidonia oceanica (L.) dead leaves: Kinetics and equilibrium studies. Chem. Eng. J. 168, 77-85 (2011).

55. Ayad, M. M., El-Nasr, A. A. \& Stejskal, J. Kinetics and isotherm studies of methylene blue adsorption onto polyaniline nanotubes base/silica composite. J. Ind. Eng. Chem. 18, 1964-1969 (2012).

56. Haque, E., Jun, J. W. \& Jhung, S. H. Adsorptive removal of methyl orange and methylene blue from aqueous solution with a metal-organic framework material, iron terephthalate (MOF-235). J. Hazard. Mater. 185, 507-511 (2011).

57. Ghorai, S. et al. Enhanced removal of methylene blue and methyl violet dyes from aqueous solution using a nanocomposite of hydrolyzed polyacrylamide grafted xanthan gum and incorporated nanosilica. ACS Appl. Mater. Interfaces 6, 4766-4777 (2014).

58. Wu, X.-L., Shi, Y., Zhong, S., Lin, H. \& Chen, J.-R. Facile synthesis of $\mathrm{Fe}_{3} \mathrm{O}_{4}$-graphene@ mesoporous $\mathrm{SiO}_{2}$ nanocomposites for efficient removal of Methylene Blue. Appl. Surf. Sci. 378, 80-86 (2016).

59. Zheng, J. et al. Synthesis of yolk-shell magnetic magnesium silicate with tunable yolk morphology for removal of methylene blue in water. J. Alloys Compd. 596, 5-9 (2014).

60. Tan, X., Lu, L., Wang, L. \& Zhang, J. Facile synthesis of bimodal mesoporous $\mathrm{Fe}_{3} \mathrm{O}_{4} @ \mathrm{SiO}_{2}$ composite for efficient removal of methylene blue. Eur. J. Inorg. Chem. 2015, 2928-2933 (2015).

\title{
Acknowledgements
}

The authors thank the Yasouj University and the Iran National Science Foundation (INSF) for supporting this work.

\section{Author contributions}

R.M.: Investigation, Writing-Original Draft, Resources, Formal analysis.D.E.: Conceptualization, WritingReview and Editing, Supervision, Visualization.M.S.: Resources, Formal analysis.

\section{Competing interests}

The authors declare no competing interests.

\section{Additional information}

Correspondence and requests for materials should be addressed to D.E.

Reprints and permissions information is available at www.nature.com/reprints.

Publisher's note Springer Nature remains neutral with regard to jurisdictional claims in published maps and institutional affiliations.

\begin{abstract}
Open Access This article is licensed under a Creative Commons Attribution 4.0 International License, which permits use, sharing, adaptation, distribution and reproduction in any medium or format, as long as you give appropriate credit to the original author(s) and the source, provide a link to the Creative Commons licence, and indicate if changes were made. The images or other third party material in this article are included in the article's Creative Commons licence, unless indicated otherwise in a credit line to the material. If material is not included in the article's Creative Commons licence and your intended use is not permitted by statutory regulation or exceeds the permitted use, you will need to obtain permission directly from the copyright holder. To view a copy of this licence, visit http://creativecommons.org/licenses/by/4.0/.
\end{abstract}

(C) The Author(s) 2021 